\title{
„ZAGREB NAM NIKAD NIJE BIO BLIŽI“: \\ SLIKA ZAGREBA U BEOGRADSKOJ ŠTAMPI I JAVNOSTI (1919. - 1929.)
}

\section{Bojan Đorđević}

UDK: 070(497.11 Beograd):304(497.5 Zagreb)“192“

Izvorni znanstveni članak

Sažetak: U radu se daje analiza pisanja beogradskih listova, a napose dva najznačajnija Politike i Vremena - o Zagrebu i njegovim stanovnicima od ujedinjenja do uvođenja Šestojanuarske diktature. Predočavaju se razni aspekti - politički, kulturni, privredni, kao i oni vezani za svakodnevni život grada. Ukazuje se na postepeno formiranje slike o Zagrebu i Zagrepčanima u beogradskom javnom mnjenju u tom periodu.

Ključne riječi: Zagreb, politika, kultura, beogradska štampa, grad, srpsko-hrvatski odnosi

\section{I. „NAROD JE KLICAO I POZDRAVLJAO“}

금 vocirajući uspomene na burne dane propasti Austrougarske i hrvatskog osamostaljenja, a potom i priključenja novostvorenoj Kraljevini Srba, Hrvata i Slovenaca, kao svedok i $\neg$ učesnik tih događaja, istaknuti srpski istoričar Vladimir Ćorović - sa pozicije jugoslovenski orijentisanog intelektualca pristiglog iz tzv. mostarskog kruga, a tokom Prvog svetskog rata stasalog u zagrebačkoj intelektualnoj sredini, u obzorju Savremenika i Književnog juga-svedočio je o naklonosti Zagrepčana prema srpskoj vojsci i njihovoj težnji za slogom i ujedinjenjem: omladina je protestovala na ulici i gde stigne. U pozorištu se daje Smrt majke Jugovića i publika prati komad silnim odobravanjem. Pevaju se narodne himne. Zagrebačke gospođe donosile su svoj nakit kao dobrotvorni prilog, a „narod je klicao i pozdravljao." Nastojeći da srpskim čitaocima ukaže na iskrenost hrvatskih težnji za jedinstvom, Ćorović je upravo Srbijancima stavljao u dužnost da bolje upoznaju Hrvate, a naročito da upoznaju njihovo središte - Zagreb. Zagreb, u njegovom viđenju, nije više smeo da bude samo me-

1 Vladimir Ćonović, „Zagrebački prevrat“, Politika (Beograd), br. 4217, 29. 10. 1919., 1-2. 
tonimijska odrednica hrvatskog nacionalnog bića, već - uz Beograd - najznačajniji jugoslovenski društveni i kulturni centar.

Ćorović je znao šta govori - i zašto to govori. ${ }^{2}$ Za razliku od Dalmacije - a posebno Splita i Dubrovnika - koja je u srpskoj političkoj, društvenoj i kulturnoj javnosti bila već decenijama percipirana kao lučonoša ideje srpsko-hrvatskog jedinstva, ${ }^{3}$ Zagreb je za srbijansko - a to će reći pre svega beogradsko - javno mnjenje bio svojevrsna terra incognita. On je to bio i u trenutku ujedinjenja, uprkos predratnim kulturnim vezama. U široj društvenoj vizuri srpske sredine, Zagreb je bio ograničeni, izdvojeni prostor, u urbanom smislu sličan Beogradu, ali supstancijalno drugačiji. Društveni procesi, dakle, mogli su biti slični, čak u pojedinim trenucima i istosmerni (sublimisani najzad u ideji jugoslovenstva i ujedinjenja), ali oni su se odvijali u posebnim, istorijski određenim sredinama, koje nisu morale biti - a nisu ni bile - u bliskoj vezi. Tzv. „posuda istorijskog grada“ “ još uvek je bila čvrsta, i Zagreb je, kao i svaki drugi grad, bio materijalizovani okvir društvenog života. Taj i takav život beogradska i uopšte srbijanska javnost trebalo je tek da upozna. A to je išlo postepeno, teško i ne uvek s blagonaklonošću.

\section{2. „ČIJI JE ZAGREB?“}

Zagreb u beogradskoj javnosti, paradoksalno, uglavnom nije bio prepoznat kao političko središte Srba u Hrvatskoj (što je uistinu u okvirima Habzburške monarhije i bio). Naprotiv, u delu te javnosti Zagreb je bio sagledavan kao simbolički eksponent austrijske - dakle antisrpske - politike! Antijugoslovensku - pa i antihrvatsku - propagandu širili su listovi već tada ozloglašenog Krste Cicvarića (Beogradski dnevnik) i takođe ne mnogo omiljenog Svetolika Savića (Balkan). Za njih je Jugoslavija bila druga Austrougarska, a Zagreb za Srbe ono što je u Austrougarskoj Beč bio za Hrvate..$^{5}$ To je eksplicitno istaknuto u nepotpisanim člancima u listu Balkan:

Mrska Austrija povampirila se i prometnula u Jugoslaviju. Ova mrzi sve što je mrzela i Austrija. Austrija mrzi na srpsko ime, mrzi ga i Jugoslavija. Austrija mrzila ideju Srbije, mrzi je i Jugoslavija. Austrija mrzila srpsku zastavu, mrzi je i Jugoslavija. Austrija mrzila i ćirilicu, mrzi je isto tako i Jugoslavija. Austrija - Jugoslavija, ista stvar! Još je ova druga u ponečem i gora od prve. ${ }^{6}$

Ovo nije ta država, o kojoj su snevala sva srpska pokolenja; ovo je nova, druga Austrija, što se zove Jugoslavija. A središte joj je Zagreb. ${ }^{7}$

$\overline{2}$ Godinu dana pre ovog članka, Ćorović je eksplicitno ustao protiv „individualističkog elementa psihe pojedinaca i čitavih pokrajina i čitavih plemena.“ IsтI, „Utisci iz Praga“, Književni jug, 4/1918., 399.

3 „Dalmacija je poslednjih godina dublje i doslednije no ikoji drugi naš kraj prihvatila ideju narodnog jedinstva.“ Jovan SKerlić, „Novi omladinski listovi i naš novi naraštaj“, Srpski književni glasnik, 30/1913., br. 3, 218.

4 Luis Mamford, Grad u istoriji, Beograd 2005., 24.

5 V. recimo: Boža S. Nikolajević, „Izlaz iz haosa“, Balkan (Beograd), br. 21, 5. 4. 1920., 1; Isti, „Istina i laž: opomena za vremena“, Balkan (Beograd), br. 55, 19. 7. 1920., 1.

6 „Ćirilica i Jugoslavija“", Balkan (Beograd), br. 84, 18. 8. 1920., 1.

7 „Skandal u Sremskim Karlovcima“, Balkan (Beograd), br. 107, 10. 9. 1920., 1. 
Ali, takvi eksplicitni stavovi, fokusirani ovoga puta na Zagreb kao simboličku oznaku antisrpskog resantimana, mogli su se pročitati i u Politici. Tako je Zagreb, posle jednomesečnog boravka u njemu, video Ranko Kovijanić, lekar iz Kruševca, i to podelio sa čitaocima beogradskog izdanja Politike:

Zagreb je onaj grad, koji je izvor sviju naših zala, jer u njemu još uvek bdi prokleta avet austrijanštine. ${ }^{8}$

Drugi su, pak, Zagreb nalazili odnarođenim gradom, koji je izgubio svoj izvorni hrvatski duh. Bar tako se to predstavljalo čitaocima Politike, ovoga puta sa naglaskom na pojačanoj autentičnosti, s obzirom da je istaknuto da je autor članka o kome je reč, izvesni Mil., Zagrepčanin koji u tom gradu živi od rođenja! Politika se, zapravo, ovim napisom priključila latentnoj antisemitskoj propagandi koju su neposredno posle Prvog svetskog rata u beogradskoj sredini vodili drugi listovi (kada je o Beogradu reč, onda se uz tzv. jevrejsku opasnost, ukazivalo redovno i na „poguban uticaj“ Cincara). Autor ovoga članka, nadovezujući se na namerno provokativan naslov, svoj napis započinje u donekle ekstatičnom i implicitno polemičkom tonu:

Čiji je Zagreb? Mnogi će razrogačiti oči, kad vidi ovaj naslov. Čiji može biti, nego hrvatski? Pa ipak, nije tako... Zagreb je i lijep i čist grad. Pa ipak, mali dio te ljepote imaju i Hrvati i Srbi u njemu, jer Zagreb je zaista lijep, ali je tuđ.?

„Tuđi“ element su Jevreji, i članak njihovu navodnu dominaciju prezentuje tako što „jevrejsku opasnost" detektuje u dve sfere - ekonomskoj i tzv. rasnoj, s tim da jedna i druga stoje u simbiozi. Kada je o ekonomskoj sferi reč, autor prebrojava radnje u Ilici i na Jelačićevom trgu, i zaključuje da su većinom jevrejske. Od deset kafana, zatim, prema njegovim tvrdnjama, samo dvema su vlasnici Hrvati - ostalima Jevreji. A samo dva hotela drže Hrvati, još dva Srbi, a sve ostale Jevreji. Na ovaj način autor članka poslužio se tipičnim postupkom antisemitske propagande, koji se sastoji u tome da:

(...) stvarni procesi marginalizuju Jevreje, ali u našoj svesti oni se pomeraju u središte. Oni personifikuju novac, pa iz materijala lažnog sećanja na Jevreje kao jedine agente prometa nastaje antisemitska slika društva u kome prividno postoji anonimna vladajuća moć, iza koje se tobože krije lična vladavina Jevreja..$^{10}$

Ta ekonomska dominacija, prema takvom viđenju, u Zagrebu je eskalirala u duhovnu i kulturnu, ${ }^{11}$ dodatno ojačana ,perfidnom“ jevrejskom mimikrijom, bilo pokatoličenjem, ${ }^{12}$ bilo samo „pohraćivanjem jevrejskih prezimena.“

8 Ranko Kovijanić, „S. H. S. ili Velika Srbija“, Politika (Beograd), br. 5451, 29. 6. 1923., 1.

9 Mil., „Čiji je Zagreb“, Politika (Beograd), br. 4348, 23. 3. 1920., 3.

10 Detlef Klausen, Granice prosvetiteljstva, Beograd 2003., 165.

11 Da je ovo drugo posledica prvog smatrao je i Rihard Vagner, tvrdeći da će Jevreji vladati kulturom sve dok „novac bude moć pred kojom sve što mi radimo gubi snagu." Richard Wagner, Das Judentum in der Musik, München 1978. , 54.

12 O ovome je pisao još Hajne, i sâm hristijanizovani Jevrejin, govoreći da „sada hrišćanstvo u celini leži u rukama Jevreja." Heinrich Heine, Werke und Briefe, t. 3, Berlin - Weimar 1980., 398. 
Istini za volju, autor članka o ,jevrejskom Zagrebu“ nije predlagao nikakve protivjevrejske mere (do njih će, kao što je poznato, u Kraljevini Jugoslaviji doći, na pritisak nacističke Nemačke, tek uoči Drugog svetskog rata), već se zalagao za pojačanu hrvatsku propagandu, a napose za „nacionalni rad“ na svim poljima - gospodarskom, intelektualnom i kulturnom:

Samo radom se može očuvati hrvatstvo Zagreba. Ako se bude i dalje plakalo i deklamovalo, onda će Zagreb prije biti Vavilon, nego hrvatski Zagreb. ${ }^{13}$

\section{3. „ONI KOJI MISLE DOBRO OVOJ ZEMLJI“}

Nekoliko godina posle ujedinjenja i kakve-takve konsolidacije države, ovakvih tonova bivalo je sve manje. Ali, opet se ne bi moglo reći da je srpska javnost uznapredovala u razumevanju Zagreba i poznavanju ovoga grada. U političkom smislu, Zagreb je bio oznaka društvene i političke svesti hrvatskih političkih stranaka, s tim što će vremenom to biti skoncentrisano na Radića i HSS - uostalom, baš kao što je i Beograd bio sublimat srpskih političkih partija, a pre svega Pašića i radikala. Dvadesetih godina prošloga stoleća u izveštajima iz Zagreba dominiraju političke teme, i to kako one od značaja za celu državu, tako i one koje bi se, uslovno rečeno, mogle svrstati u sferu lokalne politike. Od 1924. godine Politika uspostavlja dopisništvo u Zagrebu, ali od 1925. godine to još agilnije čini Vreme. Pogotovo je ovaj list bio značajan zbog razgranate mreže dopisnika. Imali su čak dvanaest stranica u tzv. provincijskim izdanjima, ali i stalne dopisnike iz najvećih gradova - Zagreba, Ljubljane, Subotice i Novog Sada. ${ }^{14}$ Stoga je ovaj list prednjačio u izveštajima iz Zagreba. Uz to, značajno je što je Vreme tih dvadesetih godina bilo antivladin list, što se naročito ispoljavalo u doba tzv. Pašić-Radićeve Vlade, tokom 1925. i u prvoj polovini 1926. godine. Tako je početkom 1926. godine Vreme, kao jedini od značajnijih listova u Kraljevini SHS, ne bez zluradosti, detaljno izvestilo, na svojoj naslovnoj strani, o stvaranju Hrvatske federalističke seljačke stranke, sastavljene od bivših članova Hrvatske seljačke stranke. Ovim poprilično senzacionalnim člankom želelo se otcepljenju jednog u suštini minornog dela zagrebačkog ogranka HSS dati mnogo veći značaj nego što je zasluživalo, pa se čak govorilo o "grupisanju Radićevih protivnika." No, i sâm izveštač Vremena morao je da primeti da „u celom Zagrebu za ovo većanje nove stranke uopšte se nije znalo. “15 $\mathrm{Pa}$ ipak, izgleda da je vlast ovu stvar shvatala ozbiljnije. Naime, odeljenje za štampu Ministarstva unutrašnjih poslova Kraljevine SHS zabranilo je izdanje ovog broja Vremena za Savsku banovinu, ${ }^{16}$ nalazeći valjda da ova vest neće u drugim delovima države izazvati nikakvog odjeka. Paradoksalno je, međutim, to što je Vreme detaljno izveštavalo o aktivnostima ove stranke, iako se snažno protivilo federalizaciji države!

13 Mrt., „Čiji je Zagreb“, Politika (Beograd), br. 4348, 23. 3. 1920., 3.

14 O ovome je u razgovoru sa B. Pekićem svedočio 1974. godine direktor Vremena Dragomir Stojadinović, brat Milana Stojadinovića. Borislav Pekić, „Vreme“ i „Novo vreme“: razgovor sa Dragomirom Stojadinovićem, Beograd 2013., 79.

15 „Nova Hrvatska Federalistička Seljačka Stranka osnovana je juče u Zagrebu“, Vreme (Beograd), br. 1459, 11. 1. 1926., 1.

16 Arhiv Jugoslavije (dalje: AJ-14), fond Ministarstvo unutrašnjih dela Kraljevine Jugoslavije, 14-68-224. 
U tom duhu kritikovane su, u tim danima, i zagrebačke gradske vlasti koje su „obezvredile veličanstvenu proslavu Hiljadugodišnjice Hrvatskog Kraljevstva.“ „Indolentna gradska uprava“, kako ju je oštro nazvao izveštač Vremena, „oglušila se o narodni osećaj tako što trgu koji još nosi rimski broj I nisu već dali ime kralja Tomislava. Ne zna se ni da li će spomenik biti postavljen na tom trgu. ${ }^{\text {"17 }}$ Zbog toga je kamen-temeljac za spomenik sklonjen u muzej.

I upravo te 1926. godine beogradska štampa naveliko je izveštavala o burnim događajima na Sveučilištu u Zagrebu. Istoga dana, 22. januara 1926. godine, i Vreme i Politika izvestili su o otpuštanju profesora sa zagrebačkog Sveučilišta, te posledično o sukobu rektora, ali i studenata sa prosvetnim vlastima Kraljevine SHS. Ipak, u ova dva beogradska lista povod odluci ministra prosvete Stjepana Radića da otpusti određene profesore različito je tumačen. Vreme je ovu Radićevu odluku predstavilo u širem smislu kao lukavi plan vladajuće koalicije HSS i radikala da se obračuna sa Samostalnom demokratskom strankom, jer je čak šest otpuštenih profesora pripadalo toj stranci. ${ }^{18} \mathrm{~S}$ druge strane, Politika je ovaj postupak videla kao šovinistički gest samoga Radića, tj. kao njegov obračun kako sa Srbima na zagrebačkom Sveučilištu, tako i sa Hrvatima jugoslovenske provenijencije, poput Grge Novaka, Viktora Novaka, Artura Šnajcera, Branka Vodnika ili Marija Kiseljaka. ${ }^{19}$ Naveden je primer Cvijićevog učenika, geografa Vojislava Radovanovića, „koji je otpušten zato što je Srbijanac koji se usudio da dođe za profesora u Zagrebu. “20 S druge strane, naglašeno je da je Mario Kiseljak otpušten samo zato što je ministru prosvete Stjepanu Radiću uputio pismo protesta protiv otpuštanja profesora zagrebačkog Pravnog fakulteta Jovana Stefanovića. ${ }^{21}$

Ove poruke Politike, kao najuticajnijeg beogradskog lista, definisale su diskurs otpora prema tadašnjoj kraljevskoj Vladi. Naime, ovakvo pisanje zaoštrilo je dotadašnju blagu nijansu opozicionog mišljenja u pravcu jasne antagonističke podele $-s$ jedne strane Ministarski savet, a s druge „svi oni koji misle dobro ovoj zemlji.“ Bilo je to veoma produktivno distanciranje od vlasti na pitanju koje nije bilo eksplicitno ideološko, a opet je itekako zadiralo u sferu politike. S druge strane, i Vreme i Politika svoj stav potkrepljivali su izveštajima o tome kakav je odjek ova Radićeva odluka izazvala ne samo na zagrebačkom Sveučilištu, već i u hrvatskom javnom mnjenju. Isticano je da se Radiću upravo u zagrebačkoj javnosti, a posebno među intelektualcima, zamera što je izneverio svoje obećanje da će kao ministar depolitizovati prosvetu: „U Zagrebu se smatra da je ovo čisto politička stvar.“22 Zbog toga nije čudno što su čitaoci bili detaljno obaveštavani o štrajku studenata na Filozofskom fakultetu u Zagrebu i o „osveti Radićevoj“ koja se ogledala u oduzimanju stipendija pobu-

17 „Kamen-temeljac za spomenik kralju Tomislavu ostavljen u muzeju“, Vreme (Beograd), br. 1451, 1. 1. 1926., 3.

18 „Oko penzionisanja zagrebačkih profesora: studenti i samostalni demokrati pokušavaju da spreče predavanja“, Vreme (Beograd), br. 1470, 22. 1. 1926., 4.

19 „G. Radić denacionalizira“, Politika (Beograd), br. 6374, 22. 1. 1926., 3.

20 Isto.

21 Isto, 3. U tom pismu Kiseljak je eksplicitno Radića optužio za šovinizam i narušavanje univerzitetske autonomije: „To znači da se ne dâ da jedan Srbin bude profesor univerziteta u Zagrebu pa ma koliko ga sâm zagrebački univerzitet birao." AJ-66, fond Ministarstvo prosvete Kraljevine Jugoslavije, 66-63-162, 19. 1. 1926.

22 „Oko penzionisanja zagrebačkih profesora: studenti i samostalni demokrati pokušavaju da spreče predavanja“, Vreme (Beograd), br. 1470, 22. 1. 1926., 4. 
njenim sveučilištarcima. Beogradskoj štampi je, štaviše, uspelo da izazove Radića da stupi u svojevrsnu polemiku sa pobunjenim studentima. Najpre su u izveštaju iz Zagreba za Politiku pohvaljeni „hrvatski studenti što su pokazali visoku državotvornu svest“ ,23 na šta je, tri dana docnije, reagovao u izjavi za Vreme sâm Stjepan Radić, ističući - u jasnoj nameri da se dodvori srpskoj javnosti - da su protiv štrajka studenata u većini bili Srbi i Crnogorci, te da su upravo oni „nosioci zdravoga razuma na zagrebačkom Sveučilištu.“ Njima nasuprot, „hrvatska djeca, a naročito zagrebačka, razmažena su dječurlija i nemaju pravu žeđ za naukom. “24 Ako je Radić mislio da će ovom izjavom izazvati simpatije srbijanske javnosti, prevario se, jer je ovu njegovu izjavu izveštač Vremena propratio surovo sarkastičnim komentarom: „Eto kako o Zagrebu misli njegov prvi predstavnik.“ ${ }^{25} \mathrm{Na}$ ove reči odmah je reagovao - a njegova izjava je objavljena u istom broju - Radićev prethodnik na mestu ministra prosvete, Svetozar Pribićević: „Radić je anacionalni element koji kleveće zdravu hrvatsku nacionalno orijentisanu omladinu. ${ }^{26}$

Karikature koje su u beogradskoj štampi pratile ovu aferu, kao i vesti o solidarisanju Univerziteta u Beogradu sa zagrebačkim profesorima i studentima, samo su doprineli Radićevom dezavuisanju i ubrzali njegovu ostavku koja je usledila 15. aprila 1926. godine. Uostalom, gotovo sve ove ocene Radićevog rada koje su se mogle pročitati u beogradskoj štampi prisutne su i u memorandumu koji je Glavna uprava Profesorskog društva Kraljevine SHS podnela 9. februara 1926. godine predsedniku Ministarskog saveta i predsedniku Narodne skupštine. I u tom memorandumu stoji da Radićeve mere kritikuju „svi oni koji ovoj zemlji dobra žele“; i tu se ukazuje na „opravdane proteste školskih radnika, ali i studentske omladine“; iznose se na Radićev račun optužbe da je „anacionalan, razoran i opasan“, te da „svesno vređa srpski deo našega naroda, unižava Slovence, a naročito ljuto progoni one Hrvate, koji sebe ne odvajaju od Srba. ${ }^{\text {"27 }}$

\section{4. „Don LAŽo“}

Svakodnevica u najvažnijim beogradskim dnevnim listovima po pravilu je ostajala potisnuta u odnosu na političku sferu, iako je upravo ta svakodnevica često izvor „normalnosti“, te merilo ljudskog trajanja u urbanoj sredini. Naravno, ne može se prenebregnuti činjenica da politika utiče na svakodnevni život, da je sa njim povezana ne samo na makronivou, već i na mikronivou svakodnevnih događaja i problema. No, to se u izveštajima iz Zagreba uglavnom ne može uočiti. Tako se vesti o izgradnji stambene železničke kolonije u Maksimiru implicitno politički semantizuju, jer se hvali Vlada, kao i zagrebačka gradska uprava, za uspešno rešenje jednog socijalnog pitanja koje „oduzima važno oružje komuni-

\footnotetext{
23 „G. Radić denacionalizira“, Politika (Beograd), br. 6374, 22. 1. 1926., 3.

24 „Budžet Ministarstva Prosvete“, Vreme (Beograd), br. 1473, 25. 1. 1926., 3.

25 Isto.

26 Isto, 4.

27 „Memorandum Glavne uprave Profesorskog društva“, Glasnik profesorskog društva za godinu 1926, Beograd 1926., $122-123$.
} 
stičkoj propagandi. ${ }^{“ 28}$ Uostalom, to se i shvatalo kao državno pitanje, jer je glavni investitor bila Direkcija državnih železnica Kraljevine SHS. ${ }^{29}$

Isto tako, kada se izveštavalo o snežnom nevremenu koje je zahvatilo Zagreb, pisalo se i o odgovornosti gradske uprave u kontekstu nesuglasica i sukoba u Gradskom poverenstvu Zagreba. ${ }^{30}$

I sukob „dveju katoličkih crkava“ i sudski postupak koji se vodio u Zagrebu nisu mogli proći bez političkih implikacija, pa i pomalo zluradih komentara izveštača Vremena i Politike na račun katoličkog klera. ${ }^{31}$ Radilo se o tužbi Marka Kalođere (u beogradskim novinama se njegovo prezime navodilo kao Kaluder!), biskupa Starokatoličke crkve (tada kanonika Stolne crkve u Splitu) protiv kanonika Zagrebačke nadbiskupije Stjepana Korežića, zbog navodne uvrede časti. Iz članaka se saznaje da je Korežić Starokatoličku crkvu nazvao „mafijom“, a biskupa Kalođeru je dosledno - čak i na suđenju - nazivao „falsifikator“ i „don Lažo“. Izveštač Vremena sa ironijom je pisao o samom sudskom procesu, o tužitelju i tuženome, ne propuštajući da istakne da se „zagrebačka publika silno zabavljala i malomalo udarala u smeh. “" ${ }^{2}$ No, ono što je ove izveštaje iz ravni svakodnevnice - pa ma bila i bizarna - prevodilo u političku sferu nije bio samo kontekst sukoba Katoličke crkve i njenih odmetnutih sveštenika, već i činjenica da je kanonik Zagrebačke nadbiskupije Stjepan Korežić bio samostalni demokrata, a da je tužilac Marko Kalođera, po sopstvenim rečima, imao simpatije za Hrvatsku seljačku stranku. A sve to - poput otpuštanja zagrebačkih profesora i štrajka studenata - dešavalo se u jeku sukoba vladajuće koalicije radikala i HSS-a sa Samostalnom demokratskom strankom i drugom opozicijom. ${ }^{33}$

\section{5. „ZAGREBAČKA KULTURA NiJE STVARALAČKA“}

Javnost u Srbiji po svemu sudeći bila je najbolje obaveštena o zagrebačkom kulturnom životu, što i nije čudno, jer su kulturne veze Zagreba i Beograda stale da se učvršćuju još u godinama uoči Prvog svetskog rata. Pa i tokom rata, u teškim danima izbeglištva, u srpskoj kulturnoj javnosti okupljenoj mahom na Krfu i u Solunu razmišljalo se o tome na koji način da se u budućoj ujedinjenoj državi osnaže srpsko-hrvatske intelektualne i kulturne veze, pre svega da bi se izvršila „emancipacija od germanskih uticaja. “34 Naglašavalo se da

28 „Novo naselje za naše železničare“, Vreme (Beograd), br. 1937, 13. 5. 1927., 3.

29 O ovoj stambenoj koloniji i njenoj izgradnji v. Darja Radović, „Željeznička kolonija u Maksimiru u kontekstu radničkih naselja nastalih u Zagrebu između dva svjetska rata“, Radovi Instituta za povijest umjetnosti, 16/1992., 199-215.

30 „Sneg i mećava u Zagrebu“", Politika (Beograd), br. 6365, 13. 1. 1926., 4.

31 „Senzacionalni proces u Zagrebu: dva biskupa, dve krvno zavađene crkve pred sudom“, Vreme (Beograd), br. 1454, 4. 1. 1926., 1; „Rat dveju katoličkih crkava u Zagrebu“, Politika (Beograd), br. 6364, 12. 1. 1926., 4.

32 „Senzacionalni proces u Zagrebu: dva biskupa, dve krvno zavađene crkve pred sudom“, Vreme (Beograd), br. 1454, 4. 1. 1926., 1 .

33 Zanimljivo je da se ova politička implikacija uglavnom nije pominjala u hrvatskoj štampi koja se bavila ovim sukobom. Jedino je u Katoličkom listu, koji je iz broja u broj izveštavao o ovom sudskom procesu i oštro napadao starokatolike, u jednom trenutku ukazano da „ovdje postoje i druge neke političke igre.“ V. Katolički list (Zagreb), br. 4, 4. 1. 1926., 55. O Marku Kalođeri i njegovom delovanju u Starokatoličkoj crkvi v. Zlatko MatıJEvić, „Otpali ili odbačeni anđeli: nastanak Hrvatske starokatoličke crkve“, Hrvatska revija, 1/2001., br. 2, 65-73; Tomislav BRANKOvIĆ, „Starokatolička crkva u Jugoslaviji“, Religija i tolerancija, 2/2004., 97-101.

34 „Naša buduća kultura“, Pravda (Beograd - Solun), br. 176, 27. 6. 1917., 1. 
upravo srpski i hrvatski književnici i umetnici imaju najveću odgovornost za buduće „duhovno zbližavanje u novoj zajednici“, kao deo „jedne zajedničke, smišljene, organizovane konstrukcije naše kulture." 35

Ipak, da posle ujedinjenja stvari nisu tekle tako glatko svedoče vajkanja o nepostojanju prave kulturne saradnje između triju centara zajedničke države, a posebno Zagreba i Beograda. Nepotpisani članak u beogradskoj Pravdi nastojao je da skrene pažnju na ovaj problem, sa jasnom porukom da bez jakih kulturnih veza i, na kraju krajeva, kulturnog jedinstva, neće biti ni političkog, ni svakog drugog zbližavanja Hrvata i Srba:

U današnjim danima, doista, postoji vrlo slaba veza kulturnog strujanja između naših glavnih kulturnih gradova. Ta bi se veza mogla sasvim izgubiti. Ali to, međutim, ne želimo. Želimo nestanak „spone“ onda, kada bi to značilo našu jedinstvenost... Hoćemo svoju kulturu, jugoslovensku kulturu. Govorimo o njenom stvaranju, gotovo uvek romantičarski, a u našim glavnim kulturnim središtima manifestuje se kulturni život na suprotne načine, pod suprotnim, gotovo, uticajima. Tu, nesumnjivo, nema jedinstvenosti. ${ }^{36}$

„Čudnom i žalosnom“ člankopisac nalazi činjenicu da u zagrebačkim listovima gotovo da nema priloga beogradskih književnika, i obratno, napominjući da je to, možda, delom iz političkih razloga, ali da je mnogo više znak indolentnosti i svojevrsnog provincijalizma. Zaključak je da se što pre mora prevladati takva „paradoksalna isključivost.“

Ipak, ne može se reći da čitaoci beogradskih dnevnih novina nisu bili obavešteni o kulturnom životu u Zagrebu. Primat je, bez svake sumnje, imalo pozorište. Gotovo da nije bilo zagrebačke premijere koja nije bila propraćena u beogradskoj štampi, često i sa opširnijom pozorišnom kritikom. Pri tome, nije se pisalo samo o Hrvatskom narodnom kazalištu, ${ }^{37}$ već i o drugim, manjim privatnim teatrima, poput Novog kazališta u kome je izvedena premijera Korolijine drame Zidanje Skadra, ${ }^{38}$ Intimnog teatra koji je svoje predstave davao u Jeronimskoj dvorani, ${ }^{39}$ ili marionetskog kazališta. ${ }^{40}$ Praćen je, takođe, rad zagrebačke Glumačke škole, njen nastavni program, ${ }^{41}$ kao i njene predstave. ${ }^{42}$ Beogradska štampa isto tako nije propuštala izvestiti i o gostovanjima stranih pozorišta u Zagrebu. U tom smislu, posebno detaljno ispraćeno je gostovanje moskovskog Hudožestvenog teatra krajem 1922. godine. Ovi članci i izveštaji nosili su u svojoj srži, naime, i neskrivenu kritiku uprave beogradskog Narodnog pozorišta na čelu sa Milanom Grolom, zbog „neuspelog pokušaja da ugovori gostovanje hudožestvenika u Beogradu. “43 Žal je bio tim veći što je Hudožestveni teatar bio u Beogradu 1920. godine, i to kada je Narodno pozorište bilo u teškom stanju,

\footnotetext{
35 Svetislav Stefanović, „Rekonstrukcija naše književnosti“, Narod (Split), br. 323, 23. 6. 1918., 1.

36 „Tri centra bez veze“, Pravda (Beograd - Solun), br. 288, 21. 10. 1923., 4.

37 Prva vest o HNK objavljena je početkom 1920. godine, i govorila je o imenovanju nove kazališne uprave. V. „Zagrebačko pozorište", Politika (Beograd), br. 4320, 22. 2. 1920., 3.

38 "Zidanje Skadra u Zagrebu“, Politika (Beograd), br. 4498, 30. 10. 1920., 2-3.

39 „Intimni teatar u Zagrebu“, Vreme (Beograd), br. 421, 20. 2. 1923., 5.

40 „Marionetsko pozorište u Zagrebu“, Vreme (Beograd), br. 668, 29. 10. 1923., 5.

41 „Glumačka škola u Zagrebu“, Vreme (Beograd), br. 353, 12. 12. 1922., 5.

42 Tako je uz velike pohvale propraćena premijera Dikensovog Cvrčka na ognjištu. „Iz zagrebačkog pozorišta“, Vreme (Beograd), br. 3, 20. 12. 1921., 3.

43 „Hudožestvenici u Jugoslaviji“, Vreme (Beograd), br. 317, 6. 11. 1922., 3.

44 „Hudožestvenici u Zagrebu“, Politika (Beograd), br. 5223, 7. 11. 1922., 4.
} 
bez glavne zgrade oštećene u ratu. A sada, u obnovljenoj zgradi i u mnogo boljim uslovima, „Beograđani, za razliku od Zagrepčana, neće videti trupu Stanislavskog. ${ }^{\text {“44 }}$

No, ni ovakve vesti iz kulturnog života nisu uvek mogle proći bez političkih konotacija. Izveštač Vremena iz Zagreba javljao je da gostovanje HNK u Beogradu, početkom marta 1924. godine, koje je prema saopštenju uprave HNK „imalo da bude izraz narodnog jedinstva“, nije u krugovima bliskim Stjepanu Radiću primljeno sa simpatijama. Štaviše, „radićevci“, kako tu skupinu, uopšteno i površno, izveštač naziva, to su saopštenje nazvali „sramnom političkom izjavom" i optužili upravu HNK da je dozvolila da im svečanu večeru u Skadarliji, u restoranu „Tri šešira“, priređuje Orjuna. Izveštač Vremena je zaključio da ovo nije većinsko mišljenje zagrebačkih kulturnih radnika i intelektualaca, ali da „treba imati u vidu da postoji i ovakav stav javnosti u Zagrebu. “45 Izveštač Vremena ovim je dopisom zapravo polemisao sa pisanjem Hrvata, lista Narodne zajednice, koja je u to vreme bila u koaliciji sa HSS. ${ }^{46}$ Verovatno ga je to ponukalo da zaključi da je takvo pisanje stav Radićeve stranke, što nije bilo sasvim tačno, jer se između te dve grupacije već uočavala nesloga koja će već sledeće godine dovesti do raskola.

Naravno, bilo je vesti i o drugim kulturnim manifestacijama u Zagrebu, o muzičkim matineima, raznim koncertima i likovnim izložbama, kao i o radu zagrebačkih izdavačkih preduzeća. Može biti zanimljivo da je prva vest u beogradskoj štampi nakon ujedinjenja koja se ticala filmske umetnosti bila upravo vezana za Zagreb. Na samom početku 1920. godine moglo se u Politici pročitati da „Zagrebačko društvo za izradu filmova priprema 'Gospođu sa suncokretom', po drami Iva Vojnovića. “47 Vesti iz književnosti ticale su se uglavnom novih izdanja, a posebno su hvaljeni napori da se značajni hrvatski književnici izdaju ćirilicom. O jednoj takvoj knjizi - Krležinoj Hrvatskoj rapsodiji u izdanju „Nove Evrope“ - opširno je, kao o „briljantnoj viziji Hrvatske“ i „vernoj slici zagrebačkog društva“ pisao Vojislav Jovanović Marambo:

Razumljivo je što je ovaj mladi pisac uspeo da za kratko vreme stekne, bar u hrvatskom delu našeg naroda, više priznanja no ijedan pisac „nove škole“, i što se jedno zagrebačko izdavačko preduzeće odlučilo na opravdani i pohvalni korak da g. Miroslava Krležu predstavi i našem srpskom delu naroda, jednom zbirkom izabranih novela ćirilicom priređenih. ${ }^{48}$

Beogradska štampa opširno je izvestila i o smrti Antuna Branka Šimića:

U svim kulturnim krugovima Zagreba danas se o njemu govorilo, što je razumljivo, kad se ima na umu, da su ga mnogi u Zagrebu smatrali za najboljeg hrvatskog pesnika. Šimić je umro u materijalnoj oskudici. ${ }^{49}$

Ponekad se o kulturnom životu Zagreba sudilo i po gostovanjima zagrebačkih umetnika u Beogradu. Jedno takvo gostovanje, pijaniste Svetislava Stančića, znameniti srpski književnik, tada u svojstvu muzičkog kritičara Vremena, Stanislav Vinaver, iskoristio je da kod

45 „Radićevci o gostovanju Zagrebačkog kazališta u Beogradu“, Vreme (Beograd), br. 809, 19. 3. 1924., 5.

46 V. „Gostovanje kazališta u Beogradu“, Hrvat (Zagreb), br. 78, 18. 3. 1924., 3.

47 „Domaći film“, Politika (Beograd), br. 4281, 1. 1. 1920., 3.

48 Vojislav M. Jovanović, „G. Krleža, ćirilicom“, Politika (Beograd), br. 4919, 1. 1. 1922., 2.

49 „Smrt Antuna Šimića“, Vreme (Beograd), br. 1211, 4. 5. 1925., 4. 
beogradskih čitalaca „razbije predrasudu“ o nadmoćnosti Zagreba kao kulturnog centra. Ne sporeći to da Zagreb ima bolje muzičke škole od Beograda, i više školovanih muzičara i dirigenata, Vinaver je ipak stao na stanovište da to nije i garancija umetničke snage i originalnosti, bar sudeći po muzičkim umetnicima koji su se predstavili Beograđanima. I sâm Stančić, „koji se u Zagrebu smatra evropski značajnim umetnikom“, nije, tvrdi Vinaver, ništa više od prosečnog pijaniste, pa taj slučaj uzima kao potvrdu svoje teze:

Zagreb nam je često slao takve svoje muzičare koji su bili pečeni u zanatu, mirni profesori, protiv kojih se ništa nema dok ostaju u granicama blagopristojnosti. Ali, sto hiljada profesora ne mogu dati jednog umetnika, i u slučaju da, recimo, Zagreb ima hiljadu prosečnih pedanata a mi ni jednog jedinog, ipak Zagreb ne bi učinio ni jedan jedini istinski sudbinski korak ispred nas. ${ }^{50}$

Iz toga je sledio zaključak da „zagrebačka kultura nije stvaralačka. ${ }^{\text {"51 }}$ Ovim svojim stavovima Vinaver je implicitno pristajao na teoriju opšteg „,rama“ za zajedničke kulture - a on je srpsku i hrvatsku kulturu nesumnjivo smatrao ne samo srodnim, već i zajedničkim - dakle na ono što bismo danas nazvali cultural modeling. Obrazac ovakvog diskursa podrazumeva utvrđenu i usvojenu paradigmu koja izriče vrednosni sud bez empirijskog utemeljenja, te ono što je pojedinačno uzdiže na nivo univerzalnog. Zagrebački i beogradski kulturni model u ovom slučaju vide se kao zadate matrice koje nisu podložne nikakvim nijansiranjima, već samo drastičnim promenama. ${ }^{52}$ Pri tome, mora se istaći da Vinaver ovom pitanju ne pristupa sa aspekta nacionalnog identiteta i nacionalnih osobenosti. U ovom slučaju Hrvati i Srbi nisu oponentni označioci zagrebačke i beogradske kulturne sredine. Radi se o identitetu Grada kao kulturnog areala. Uostalom, sâm pijanista Stančić je bio Srbin (i zbog toga u vreme NDH otpušten iz Muzičke akademije u kojoj je od 1927. godine predavao). Dakle, Vinaverova kritika zagrebačke, modernim rečnikom rečeno „kulturne scene“, nije heteroimagološka, već nastoji da pruži sliku kulturnog označenja pojava i osobina zagrebačke sredine, nalazeći slične stvari i u beogradskoj. Za Vinavera je, dakle, Zagreb „naš grad“, kako to eksplicitno kaže, i sameravanje sa Beogradom nikada ne teče na opozitnoj ravni: svoj - tuđ.

Ipak, ta opozicija u Vinaverovom tekstu postoji, ali ne između Zagreba i Beograda. Naime, na putu formiranja svojih postulata o narodnosnoj osnovi autentične srpske i hrvatske (i skupno jugoslovenske) kulture kao garantu umetničke originalnosti i kvaliteta, a koje će naročito zastupati u tridesetim godinama prošlog veka, Vinaver i Zagreb i Beograd, gradove koje smatra svojim, suprotstavlja evropskoj kulturi kao „okamenjenoj tradiciji“. Transcedentiranje te kulture, koje je, prema Vinaverovom uvidu, u Zagrebu bilo jače izraženo nego u Beogradu, ne doprinosi nastanku umetnički vrednih dela, ,jer je kopija“. Šta je, onda, ono čime, i po čemu, i Zagreb i Beograd treba da budu svoji? To je ono što Vina-

50 Stanislav Vinaver, „Kultura g. Stančića“, Vreme (Beograd), br. 1075, 15. 12. 1924., 4.

51 Isto.

52 O ovome v. Paul J. VAN DEN Brink, „Value orientations as an assessument tool in cultural diversity“, Nursing Research, 33/1984., br. 4, 198-203; Tom GallaGHer, „Value orientations and conflict resolution: Using the kluckholn value orientations model“, u: Finding the middle ground: Insight and applications of the value orientations model (ur. Kurt W. Russo), Yarmouth 2000., 185-194. 
ver eksplicitno naziva „balkanskim mentalitetom.“ Odricanje od toga, koje je u Zagrebu uveliko uzelo maha, a sve više se primećuje i u beogradskoj kulturnoj sredini, pogubno je, prema Vinaverovom mišljenju, jer guši one „životne sokove“ koji proističu iz izvornih mentalitetskih kodova. Tako Vinaver na kraju ipak uspostavlja opoziciju: svoj - tuđ, ali ne na ravni Zagreba i Beograda, niti hrvatske i srpske kulture, već na ravni: jugoslovenska (balkanska) kultura - zapadnoevropska kultura. Bežeći od površnih tretiranja Zagreba kao srednjoevropskog i Beograda kao balkanskog grada, Vinaver je ipak podlegao jednom od osnovnih stereotipa koji su upravo Evropljani imali o balkanskoj kulturi kao primitivnoj, ali organski čistoj. ${ }^{53}$

\section{6. „ZAGREB, NǍ̌ BRAT“}

Najtemeljnija, istorijski i mentalitetski najindikativnija slika Zagreba u beogradskoj štampi u posmatranom periodu potiče iz pera Miloša Crnjanskog. Ova reportaža u nastavcima (u četiri broja lista Vreme), koja sadrži i izrazite putopisne elemente, danas se uopšte ne pominje kada se piše o Crnjanskom kao publicisti i putopiscu, a razlog tome je taj što njeno spominjanje ne odgovara onom diskursu u Srbiji koji stvara sliku Crnjanskog kao izrazitog srpskog nacionaliste. Upravo u ovim svojim tekstovima sa zajedničkim nadnaslovom „Zagreb u prošlosti i sadašnjosti“, Crnjanski se ukazuje kao pronicljivi posmatrač, odličan poznavalac istorije (koju je, uostalom, i diplomirao na Filozofskom fakultetu u Beogradu), te kritički nastrojen, ali objektivan prosuditelj zagrebačkih političkih i kulturnih prilika, koji - što je najvažnije - ne piše samo sa aspekta komparacije Zageba i Beograda (iako od toga ne beži, naprotiv), već nastoji da beogradskoj javnosti pruži i sliku Zagreba per se. On piše otvoreno i sa izrazitom naklonošću prema Zagrebu i Zagrepčanima. A ako je u nečemu primetan kritički ton, ako je na neke negativnosti ukazano, onda je to ono što je Crnjanskog u to doba karakterisalo i u putopisima iz Italije i Nemačke, kao i u tekstovima o Vojvodini - izraziti antiklerikalizam (sa jasno naglašenim ateizmom) i antielitizam. Stoga je najkritičkije zasnovan prvi deo reportaže, u kome Crnjanski oštro antagonizuje Zagreb „kraljeva i popova“ i Zagreb „hrvatskog naroda“. Ta opozicija postoji i u njegovo vreme, i on je uočava i kao ideološki, ali i kao politički problem:

Još danas postoji najstariji deo Zagreba, dvor vladika, zidine i kule popovske, iz kojih se nekada vladalo dušom Hrvata. Po izgledu, danas popovština više ne može da vlada seljačkim Hrvatima, ali samo po izgledu. Dovoljno je provesti jedne uskršnje praznike u Zagrebu i okolini, videti hiljade koje se ispovedaju, pričešćuju i mole, da bi se steklo duboko uverenje da će katoličko sveštenstvo i hrvatski biskupi igrati važnu ulogu u sudbini naše države, kao što su imali važnu ulogu u prošlosti Hrvatske, teškoj i gorkoj. ${ }^{54}$

\footnotetext{
53 Doduše, u to vreme Vinaver nije bio jedini koji je ovako sudio. Slične rezerve prema uticaju zapadnoevropske kulture na jugoslovensku ispoljavali su (sem, najeksplicitnijih u tome, zenitista) i Dragiša Vasić, Miloš Crnjanski, pa čak, u manjoj meri, i Miroslav Krleža. V. Gabriela ŠUBERT, „Imaginarna geografija 'Balkana' iz suprotnih perspektiva i njihove manifestacije u književnim delima“", u: Svoj i tud-slika drugog u balkanskim i srednjoevropskim književnostima: zbornik radova (ur. Miodrag Maticki), Beograd 2006., 27-28.

54 Miloš Crnjanski, „Kaptol, stari Zagreb“, Vreme (Beograd), br. 1218, 11. 5. 1925., 3.
} 
Ta diskrepancija dvaju pogleda na život i politiku ogleda se naročito u razgovoru Crnjanskog sa nadbiskupom Antunom Bauerom. Razmimoilaženja između njih dvojice ne potiču ni iz nacionalne vizure, ni iz konfesionalne pripadnosti. Ona su proizvod sukoba starog (klasnog, klerikalnog, nacionalističkog) i modernog (antielitističkog, verski indiferentnog i integralističkog) duha. Iako verno prenosi Bauerove reči, Crnjanski kritičkim komentarima vrši destrukciju nadbiskupovog svetonazora, bilo direktnim referencama (,on se ne smeši“; „kaže bez ikakvog izraza na licu“; „vidi se da mu je teško sa Beogradom“), bilo ironičnim opaskama, poput one o „strahotama“ agrarne reforme koja je pogodila Katoličku crkvu u Kraljevini SHS. Jasan je stav Crnjanskog da Srbi i Hrvati moraju da napuste okoštale klerikalne matrice i da se nađu na tzv. narodnosnoj osnovi, jer „krajnje je vreme da se Srbi i Hrvati zaljube jedno u drugo." ${ }^{55}$

Da bi se to desilo, Crnjanski je rešio da u drugom delu reportaže prikaže ne samo „istorijski Zagreb“, koji je „mrtav i tih, kao da je razočaran i uvređen od onoga, što se dole, u sadašnjosti zbiva," ${ }^{56}$ već i razmišljanja zagrebačkih intelektualaca. Njihova rezonovanja sažeo je u gotovo aforističke iskaze. Obaveštavajući beogradske čitaoce da „Zagrepčani izuzetno duhovito i pronicljivo rasuđuju politički“, Crnjanski je naveo neke od britkih i ironičnih opaski: „Hrvati i Srbi su antidržavni; državotvorni u ovoj zemlji su samo Nemci i Mađari, a naročito Jevreji“; „Da su Srbi pametni, poklonili bi nama Hrvatima još sto godina istorije“; „Radićevci - ma to su Obrenovićevci“". 77

Ipak, najznačajnija su poslednja dva dela reportaže. U prvom od njih, Crnjanski je pokušao da pokaže šta to spaja Hrvate i Srbe, šta je to što je jače od svega što ih je delilo u prošlosti, i najzad - šta je to što Beograd i Zagreb imaju da ponude kao zalog zajedništva. Treći svoj tekst Crnjanski započinje gotovo lirskim pasažom:

Kad bi jedan pesnik, pisac romana, ili stari političar hteo da živi tiho i mirno, pri tome da se oseća u toploti i gospodstvu naše prošlosti, trebao bi da se nastani u zagrebačkom Gornjem Gradu, u tišini crkava, dvorova, vrtova i rascvetanih voćaka. ${ }^{58}$

Ali, odmah zatim, Crnjanski daje svoje viđenje zagrebačke i hrvatske prošlosti, nalazeći da je Zagreb tek po nuždi hrvatska prestolnica, te da je njegov istorijski značaj za Hrvate „preuveličan“, ali da Zagrepčanima „teško pada da čuju istinu“:

A ta je istina, da je hrvatska država umrla u Primorju, davno pre srpske, i da je srčika hrvatske zemlje južnije od današnjeg centra i u onom kraju, gde se hrvatska zemlja meša sa srpskom. Selidbom i bekstvom premestilo se srce Hrvatske tako daleko na sever, u grad koji je stolećima bio tuđinski, kao što se i srce srpstva premeštalo daleko na sever. Samo je to Hrvate skupo stalo i staće ih još, kao što bi bilo i Srbe skupo stalo, da nije bilo srbijanskih ustanaka i da je centar srpski bio ostao u Novom Sadu..$^{59}$

Naravno, u mnogim stvarima Crnjanski nije bio sasvim u pravu povlačeći ove srpskohrvatske analogije. To, međutim, proističe iz njegove opijenosti Hrvatskim primorjem, o

\footnotetext{
55 Isto.

56 Isti, „Grič, istoriski Zagreb“, Vreme (Beograd), br. 1219, 12. 5. 1925., 4.

57 Isto.

58 Isti, „Zagreb, naš brat“, Vreme (Beograd), br. 1220, 13. 5. 1925., 5.

59 Isto.
} 
kome je više puta i u svojim reportažama i putopisima, i u svom romanu Kod Hiperborejaca, pisao sa oduševljenjem, te sa izlivima ogorčenosti zbog italijanskih pretenzija na hrvatski deo Jadrana (protiv čega se, uostalom, zdušno i iskreno borio krajem tridesetih godina prošloga stoleća dok je bio ataše za štampu pri jugoslovenskom poslanstvu u Rimu). $\mathrm{U}$ svom viđenju istorijskih procesa, Crnjanski je upotrebio veoma nategnutu analogiju sa Velikom seobom Srba u Vojvodinu i Južnu Ugarsku. Takve seobe, i u tom obimu, iz Primorja na sever Hrvatske nije bilo. Ipak, suština ovog napisa Crnjanskog jeste u nastojanju da se progovori o hrvatstvu Zagreba koje, sa autorove tačke gledišta, nije u prošlosti bilo ni samorazumljivo, ni neupitno. Zagreb je, smatra Crnjanski, tek u moderno doba - a to će reći od polovine devetnaestog stoleća - postajao postepeno hrvatsko središte, simbol raznolikosti hrvatskog mentaliteta. Sve dotle on je bio „ugašeno ugljevlje“ narodnosne samobitnosti, svedeno na aristokratsko područje odrođeno od naroda, pa samim tim i od „srži hrvatstva“. Poslednji ostaci - a Crnjanski, kao antielitista, ne krije radost što su poslednji - još se mogu naći u Gornjem Gradu, na Griču koji „spava i ne zna za sve ono što se odvija u Zagrebu, ili Beogradu. “60 A upravo taj pravac u kome savremeni Zagreb ide dovešće ga, uveren je Crnjanski, na istu tačku gde je i Beograd. Kao što je Beograd, uprkos svim istorijskim izazovima, postao srce srpske nacije, tako će i Zagreb biti srce hrvatstva.

A da je tako, govori poslednji deo reportaže Crnjanskog, poslednji napis u kome on iznosi argumente za to da je Beograd doduše bio nacionalno svesniji, ali da je Zagreb izgradio urbanu kulturu do koje Beograd tek treba da dopre. Tako se ova istorijska paralela u napisu Crnjanskog profilirala na sledeći način: Beograd je istorijski „svesniji“, ali urbano zaostao; Zagreb tek treba da osvesti svoju istoriju, ali je urbano formiran:

Kad voz uđe u stanicu, pojavi se moderni i lepi Zagreb. Dok Beograd u sebi još krije palanku, nečistoću i naoko brutalan život, dotle je Zagreb odmah pred stanicom jedan od najlepših manjih gradova u Evropi. Parkovi i pljusak šedrvana, dug red velikih palata, velikovaroški oblici, široka avenija, vanredna kaldrma, varoški svet. Tu je Akademija sa odličnim zbirkama, i tek otvoreni hotel Esplanada, najveći hotel u državi i na Balkanu. Taj novi Zagreb... postao je državotvoran i pomagaće vladu, a prevrat mu ne pada ni na pamet. Ono što je najbolje u njemu, to je jedan kolektivno građanski, varoški osećaj, ljubav prema svome gradu i jedna zbilja silna opštinska delatnost. ${ }^{61}$

Tako Crnjanski iz ravni pedantnog opisa zagrebačkog urbanog miljea prelazi na politički diskurs o zagrebačkoj i hrvatskoj državotvornosti. A iz tog diskursa, samo nešto docnije, preći će na ravan ideološke glorifikacije jedinstva Hrvata i Srba, čemu potvrdu nalazi u stalnoj postavci zagrebačkog Etnografskog muzeja: „U tim zbirkama je beskrajan nacionalni optimizam, veza i jedinstvo (kurziv - B. Đ.).“62 Crnjanski, pritom, ne propušta priliku i za

60 Isto.

61 Isti, „Zagreb, bez svoga naličja“, Vreme (Beograd), br. 1222, 15. 5. 1925., 4.

62 Isto. Zanimljivo je da je vrlo slične impresije o Zagrebu imao i kolega Crnjanskog, i književni i nastavnički (obojica su u to vreme radili kao profesori Četvrte muške gimnazije u Beogradu), Momčilo Nastasijević. On je od 1. do 10. maja 1926. godine vodio svoje učenike na ekskurziju do Zagreba, Sušaka, Šibenika, Splita i Plitvica. Po povratku je podneo zanimljiv i iscrpan izveštaj (čuva se u Arhivu Jugoslavije, pod signaturom: AJ-66-674-1129, a objavio ga je Novica Petković u četvrtoj knjizi Sabranih dela Momčila Nastasijevića, Beograd - Gornji Milanovac 1991., 552-560), koji se odlikuje minucioznim zapažanjima o samom Zagrebu i njegovim stanovnicima, ali i o reakciji beogradskih učenika koji su prvi put boravili u Zagrebu. Nastasijevićev izveštaj prepun je divljenja prema Zagrebu i Zagrepčanima, a i on 
ironične opaske. Navodeći da u predvorju Etnografskog muzeja stoji spomen-ploča posvećena „Velikom Kralju Njegovom Veličanstvu Petru I Osloboditelju“, on dodaje: „Kao što vidite, nije Zagreb baš uvek republikanski. Ponedeonikom, sredom i petkom - kad radi muzej. “'33 U svakom slučaju, članke Crnjanskog možemo posmatrati kao jedinstvenu putopisnu reportažu o Zagrebu, koja ima i svoje umetničke domete, ali koja je, prevashodno, usmerena ka nastojanju da srpskim čitaocima približi mentalitet Zagrepčana, te da ukaže na one momente koji ometaju, a još više na one koji doprinose državnom jedinstvu. Kao takva, ova putopisna reportaža biće, na svoj način, preteča onima koje će se o Zagrebu pojaviti u beogradskim novinama po proglašenju diktature.

\section{7. "ZAGREB U CRNINI“}

Vesti i širi izveštaji iz Zagreba u beogradskoj štampi stali su da se umnožavaju posle ubistva i ranjavanja hrvatskih poslanika u Skupštini 1928. godine. Osim političkih izveštaja i komentara, izveštači su nastojali da pokažu čitaocima i reakciju tzv. javnog mnjenja, tj. samih Zagrepčana. Posebno je u tome prednjačilo Vreme, čiji je dopisnik slao nekoliko vrsta tekstova - političke komentare koji su bili odmereni i uglavnom nastojali da objektivno prikažu novonastalu situaciju; intervjue sa zagrebačkim političarima, privrednicima i tzv. javnim radnicima; reportaže o životu u Zagrebu tokom leta 1928. godine. Ton ovih članaka bio je oprezan i suzdržan, u skladu sa naporima vlasti da ublaže posledice atentata, a postojale su dve ciljne grupe. Jedna su bili beogradski čitaoci, kojima se predočavalo kakve je posledice atentat ostavio na „duše i srca“ Zagrepčana. Dopisnik nije skrivao vesti o nemirima i nacionalističkim ispadima, ali je pre svega isticao dostojanstvo Zagrepčana. Beogradska i uopšte srpska javnost pozivana je da razume njihovu tugu i gnev:

Mora se shvatiti tuga, ogorčenje, pa čak i bes Zagrepčana. Oni nisu, i ne mogu biti, indiferentni, i mi smo to dužni imati u vidu kada sudimo o onome što se dogodilo. ${ }^{64}$

S druge strane, naročito posle smrti Stjepana Radića, napisi u beogradskim listovima bili su usmereni i ka hrvatskim čitaocima, kojima se predočavalo da srpski narod ne stoji uz „pomahnitale zločince“, i da je rešenje u jačanju političkih i svih drugih veza između Beograda i Zagreba. ${ }^{65}$ Slika Zagreba u danima tuge bila je donekle patetizovana, ali data sa simpatijama i naklonošću, te sa puno detalja:

se, kao i Crnjanski, divi zgradama, kulturnim ustanovama poput Akademije, Univerziteta ili Nacionalne i sveučilišne knjižnice, koje dokazuju da su Zagrepčani „nacionalno svesni ljudi“. Zapazio je i „lepo popločane ulice“ (onu „vanrednu kaldrmu“ koju je uočio i Crnjanski), što primećuju i učenici, koji se dive tome što, iako kiša pada već tri dana, na ulicama nema blata kao u Beogradu! No, Nastasijević je, baš kao i njegov kolega Crnjanski, prepun optimizma, naročito posle posete Etnografskom muzeju, za koji je i on zaključio da je simbol jedinstva: „Tu se više ne delimo na Srbe i Hrvate, tu su samo varijante jedne te iste osnovne psihe svih južnih Slovena." O ovom Nastasijevićevom izveštaju više: Bojan ĐorĐević, Plemenita misija ili muka živa: srpski književnici kao profesori, Beograd 2018., 88-91.

64 „Zagreb posle tragičnih događaja“, Vreme (Beograd), br. 2336, 26. 6. 1928., 4.

65 „Žalost Zagreba“, Vreme (Beograd), br. 2380, 9. 8. 1928., 1. 
Danas je Zagreb sav u crnini. Crne zastave na kućama, izlozi prevučeni crninom, crne zastavice na automobilima i tramvajima, zatvorene radnje; šapatom se sreću poznanici na ulicama, listovi uokvireni crninom, zabrinutost na licima starijih i grozničavost kod mlađih, dok teški zvuci velikog zvona sa katedrale odjekuju odmereno i uzbudljivo. Čitava varoš ima istovremeno svečan i tužan izgled. ${ }^{66}$

Politika nije imala stalnog dopisnika iz Zagreba, pa je tamo bio poslat jedan od najboljih novinara, Bora Prodanović, sin Jaše Prodanovića. Zanimljivo je da je Bora Prodanović, inače levičar po opredeljenju, veliki deo svoga izveštaja posvetio Radiću kao borcu za socijalnu pravdu, razgovarajući pre svega sa radnicima. Prodanović je isticao „privrženost radnika“ Radiću, i smelo doneo mišljenje jednog od njih da je „za nas radnike Radić isto ono što je

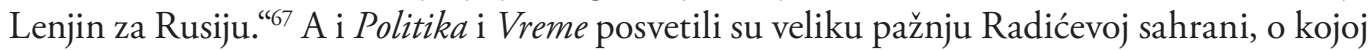
je Politika izvestila na čitavih šest strana, ${ }^{68}$ a Vreme na pet. ${ }^{69}$

U sledećim mesecima na stranicama beogradskih listova dominirale su političke teme, vezane za pokušaje postizanja dogovora između hrvatske i srpske strane. Kao i danas, kao i uvek u sličnim situacijama, do čitalaca su dopirali isključivo optimistični glasovi, iz kojih se nisu dale naslutiti prave političke implikacije. Zato je bilo moguće da još i početkom januara 1929. godine, posle razgovora sa kraljevim izaslanikom koji je uoči novogodišnjih praznika posetio Zagreb, Politikin novinar zaključi da je neminovno da se situacija po-

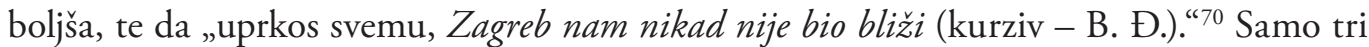
dana posle ovih reči, ista ta Politika, kao i svi drugi listovi u državi, objavili su proglas kralja Aleksandra o uvođenju diktature. U radikalno novim okolnostima, u jugoslovenskom integralističkom diskursu, radiće se na tome da se Zagreb još više približi beogradskom i srpskom javnom mnjenju, a tekstovi o svakodnevnom životu u Zagrebu - gospodarskom, kulturnom i svakom drugom - biće još više zastupljeni u beogradskim listovima, ali i izrazitije ideološki i politički jednoznačni. U tom smislu, taj period predstavljaće s jedne strane nadogradnju onoga što se beogradskoj i srpskoj javnosti nastojalo predočiti u prvoj deceniji posle ujedinjenja, ali s druge strane i rupturu. Publicisti i književnici pokušaće da se, manje ili više vešto, kreću između ta dva pola. No, ipak, temelj za shvatanje Zagreba i njegovog mesta u politici, kulturi i privredi zajedničke države postavljen je u periodu koji smo nastojali da analiziramo. Čitaoci budućih napisa imali su, sada, realnije i svestranije viđenje jednog od dvaju centara Kraljevine.

\section{$\cos$}

$\overline{66}$ „Zagreb u crnini“, Vreme (Beograd), br. 2381, 10. 8. 1928., 3.

67 Bora Prodanović, „Zagreb posle smrti Stjepana Radića“, Politika (Beograd), br. 7283, 10. 8. 1928., 2.

68 „Svečana sahrana Stjepana Radića“, Politika (Beograd), br. 7286, 13. 8. 1928., 1-6.

69 „Pogreb Stjepana Radića“, Vreme (Beograd), br. 2384, 13. 8. 1928., 1-5.

70 Politika (Beograd), br. 7429, 3. 1. 1929., 3. 


\section{“NEARER TO US THAN EVER": THE PERCEPTION OF ZAGREB BY THE PRESS AND PUBLIC OF BELGRADE (I9I9 - I929)}

Summary: At the moment of unification, Zagreb was something of a terra incognita for the Serbian public, which is to say, Belgrade. This was true in spite of the cultural ties that connected the two cities since before the war. The Serbian public perceived Zagreb as a narrow, detached place which may have resembled Belgrade in its urbanity, but was nonetheless substantially different. At first, the Belgrade public, or parts of it, failed to recognize Zagreb as the political center of Serbs in Croatia (a role it had undoubtedly played within the Habsburg Monarchy), regarding it instead as the symbolical extension of Austrian politics - and thus as being essentially anti-Serb. The latter view gradually subsided in the years that followed the unification, as the state consolidated, to whatever extent. Nevertheless, it would be wrong to claim that the Serbian public gained a more in-depth knowledge or understanding of the city. Politically, Zagreb embodied the social and political awareness of Croatian political parties, which eventually came to mean Radić and the Croatian Peasant Party; the same was true of Belgrade and Serbian political parties, above all Pašić and the Radicals. In the 1920s, press reports from Zagreb were dominated by political topics, those relevant to the entire country and those of, so to speak, local import. However, the Serbian public seems to have been best acquainted with the cultural life of Zagreb, unsurprisingly if we bear in mind that the cultural ties between the two cities predated the World War. The theater was the most notable in this regard: there was hardly an opening night in Zagreb that was not reported on by the press in Belgrade, and the reports were often accompanied by full reviews. Of course, other cultural events in Zagreb also received due attention, such as musical matinées, various concerts and art exhibitions, as well as the output of publishing companies. Interestingly enough, the first post-unification piece of news regarding film was also related to the city. Additionally, some of the most notable Serbian writers, such as Stanislav Vinaver or Miloš Crnjanski wrote about the historical and political realities of cultural life in Zagreb. Moreover, reports from Zagreb grew in number after the wounding and assassination of Croatian MPs in the Belgrade Assembly in 1928. In addition to reporting and political commentary, journalists attempted to provide their readers with insight into the so-called public opinion, and the attitudes of the citizens of Zagreb. After the establishment of the $6^{\text {th }}$ January Dictatorship, efforts would be made to bring Zagreb even closer to the public of Belgrade and Serbia, so everyday life in its various aspects (economic, cultural and otherwise) would be written about with increasing frequency, yet with equally increasing ideological and political uniformity. The foundations for the understanding of Zagreb and its position in the politics, culture and the economy of the kingdom were established in the period we attempted to analyze in this paper. The readers of future press reports would therefore have a more rounded, more realistic view of one of the two centers of the realm.

Key words: Zagreb, politics, culture, the Belgrade press, the city, Serbian-Croatian relations 


\section{Izvori}

Arhiv Jugoslavije (AJ)

AJ-14, fond Ministarstvo unutrašnjih dela Kraljevine Jugoslavije.

AJ-66, fond Ministarstvo prosvete Kraljevine Jugoslavije.

Balkan (Beograd), 1920.

Hrvat (Zagreb), 1924.

Katolicki list (Zagreb), 1926.

Narod (Split), 1918.

Politika (Beograd), 1919. - 1920., 1922. - 1923., 1926., 1928. - 1929.

Pravda (Beograd - Solun), 1917., 1923.

Vreme (Beograd), 1921. - 1928.

\section{Literatura}

Tomislav Branković, „Starokatolička crkva u Jugoslaviji“, Religija i tolerancija, 2/2004., 93-104.

Vladimir Ćorović, „Utisci iz Praga“, Književni jug, 4/1918., 399.

Bojan ĐorĐević, Plemenita misija ili muka živa: srpski književnici kao profesori, Beograd 2018.

Tom Gallagher, „Value orientations and conflict resolution: Using the kluckholn value orientations model", u: Finding the middle ground: Insight and applications of the value orientations model (ur. Kurt W. Russo), Yarmouth 2000., 185-194.

Heinrich Heine, Werke und Briefe, t. 3, Berlin - Weimar 1980.

Detlef Klausen, Granice prosvetiteljstva, Beograd 2003.

Luis Mamford, Grad u istoriji, Beograd 2005.

Zlatko Matıjević, „Otpali ili odbačeni anđeli: nastanak Hrvatske starokatoličke crkve“, Hrvatska revija, 1/2001., br. 2, 65-73.

„Memorandum Glavne uprave Profesorskog društva“, Glasnik profesorskog društva za godinu 1926, Beograd 1926., 122-123.

Borislav Pekić, „Vreme“ $i$ „Novo vreme“: razgovor sa Dragomirom Stojadinovićem, Beograd 2013.

Darja RADović, „Željeznička kolonija u Maksimiru u kontekstu radničkih naselja nastalih u Zagrebu između dva svjetska rata", Radovi Instituta za povijest umjetnosti, 16/1992., 199-215.

Jovan Skerlić, „Novi omladinski listovi i naš novi naraštaj“, Srpski književni glasnik, 30/1913., br. 3, 218.

Gabriela ŠuBERT, „Imaginarna geografija 'Balkana' iz suprotnih perspektiva i njihove manifestacije u književnim delima“, u: Svoj i tud-slika drugog u balkanskim i srednjoevropskim književnostima: zbornik radova (ur. Miodrag Maticki), Beograd 2006., 17-30.

Paul J. VAn DEN BRInk, „Value orientations as an assessument tool in cultural diversity“, Nursing Research, 33/1984., br. 4, 198-203.

Richard Wagner, Das Judentum in der Musik, München 1948. 